\title{
TINGKAT RELIGIUSITAS TERHADAP KECURANGAN AKADEMIK PADA MAHASISWA AKUNTANSI DI SEKOLAH TINGGI ILMU EKONOMI (STIE) MADANI BALIKPAPAN
}

Chairun Nisa, Pipin Fitriasari

e-mail: chairun.nisa.8181@gmail.com

\author{
fitriasari_pipin@yahoo.co.id
}

This research aims to analyze the effect of fraud diamond and the level of religiosity on academic fraud. The population of this research is STIE Madani Balikpapan bachelor degree students who have taken semester 4 above. The sampling technique uses purposive sampling and the total sample is 75 respondents. Data collection of this research used questionary method. Analysis method is Structural Equation Modeling (SEM) with Partial Least Square (PLS) and SmartPLS 3.0 as analysis tools. The results showed that capability had a positive effect on academic fraud. While pressure, opportunity, rasionalization, and the level of religiosity do not affect on academic fraud.

Keywords: fraud diamond, pressure, opportunity, rasionalization, capability, the level of religiosity, academic fraud.

\section{PENDAHULUAN}

Pendidikan adalah proses pembelajaran yang bertujuan mengembangkan potensi sumber daya manusia dari berbagai segi yang diturunkan dari satu generasi ke generasi berikutnya agar dapat berguna bagi dirinya sendiri, masyarakat, bangsa dan negara. Mahasiswa merupakan orang yang belajar dan menerima pendidikan dengan jenjang tertinggi pada perguruan tinggi seperti universitas, akademi, dan sekolah tinggi. Banyak orang yang menganggap bahwa mahasiswa adalah kaum intelektual yang tahu segalanya dan mampu menyelesaikan semua masalah (Ridhayana, Ansar dan Mahdi, 2018). Untuk mencapai ekspektasi yang diharapkan oleh lingkungan di sekitarnya, banyak mahasiswa yang berorientasi pada hasil akhir yang baik untuk mencapai tujuan mereka. Hasil tersebut dapat diperoleh apabila mereka memperoleh nilai yang baik selama masa perkuliahan.

Kebutuhan tersebut membuat mahasiswa melakukan berbagai cara untuk memperoleh nilai yang mereka inginkan sehingga dapat menyebabkan timbulnya praktik kecurangan atau kecurangan akademik (academic fraud). Menurut Sari, Rispantyo dan Kristianto (2017) berbagai tindakan kecurangan akademik dilakukan mahasiswa dengan berbagai alasan dan tujuan, dimana tindakan kecurangan yang dilakukan antara lain adalah mencontek saat ujian, menyalin jawaban teman, copy paste dari internet tanpa menyebutkan sumbernya, tidak hadir 
kuliah tetapi titip tanda tangan, membuat contekan saat ujian, meminta bantuan teman saat ujian, serta bekerjasama dengan teman saat ujian.

Ajzen (1991) menyatakan terdapat berbagai alasan yang dapat mempengaruhi perilaku seseorang. Setiap orang memiliki tujuan-tujuan yang ingin dicapai dan untuk mencapai tujuan tersebut seseorang harus memiliki motivasi. Masing-masing individu memiliki motivasi yang berbeda-beda sesuai dengan tujuan yang hendak dicapai (Zamzam, Mahdi dan Ansar, 2017). Cressey (1953) dalam Tuanakotta (2012: 205) menyatakan bahwa terdapat tiga faktor yang mempengaruhi kecurangan yaitu tekanan (pressure), kesempatan (opportunity) dan rasionalisasi (rationalization). Namun Wolfe dan Hermanson (2004) berpendapat bahwa terdapat satu faktor tambahan yang dapat mempengaruhi kecurangan yaitu kemampuan (capability) sehingga keempat faktor tersebut disebut fraud diamond.

Tekanan (pressure) merupakan faktor dalam teori fraud diamond yang dapat mempengaruhi kecurangan akademik. Tekanan merupakan situasi dimana seseorang merasa perlu memilih melakukan kecurangan. Menurut Zamzam, Mahdi dan Ansar (2017), mahasiswa biasanya memiliki tekanan internal maupun eksternal. Tekanan bisa timbul karena adanya kebutuhan untuk memperoleh nilai yang bagus selama pelajaran. Faktor kedua dalam fraud diamond yang dapat mempengaruhi kecurangan akademik adalah kesempatan (opportunity). Mahasiswa mendapatkan kesempatan untuk melakukan kecurangan akademik karena ada kelemahan dari pengendalian internal perguruan tinggi. Pada saat ujian, mahasiswa bisa mencontek atau saling bekerja sama apabila kurang adanya pengawasan yang ketat dari dosen pengawas.

Faktor ketiga adalah rasionalisasi (rationalization). Rasionalisasi adalah sikap pembenaran dari tindakan kecurangan yang dilakukan oleh seseorang (Widianto dan Sari, 2017). Mahasiswa yang melakukan kecurangan dapat berpikir bahwa mencontek bukan perbuatan yang salah dengan menggunakan berbagai alasan (Artani dan Wetra, 2017). Faktor keempat dalam fraud diamond yang dapat mempengaruhi kecurangan akademik adalah kemampuan (capability) (Wolfe dan Hermanson, 2004). Pelaku kecurangan akan sulit untuk bertindak apabila tidak memiliki kemampuan tertentu. Pada saat melakukan kecurangan akademik, tentu saja mahasiswa harus mempunyai kemampuan yang memadai. Misalnya pada saat mencontek mahasiswa harus mampu melakukannya tanpa sepengetahuan dosen pengawas. Mereka harus mampu menekan rasa stres dan bertindak seolah-olah tidak melakukan tindakan curang apapun. 
Faktor lain yang dapat mempengaruhi kecurangan akademik yaitu tingkat religiusitas. Tingkat religiusitas merupakan tingkat kepercayaan manusia kepada Tuhan yang Maha Esa. Mahasiswa sebagai manusia beriman tentu memiliki akhlak (Aziz dan Novianti, 2016). Mahasiswa yang memiliki akhlak tinggi cenderung jarang melakukan kecurangan akademik karena ada perasaan bersalah atau berdosa jika melakukan perbuatan curang yang tidak bermoral. Sedangkan apabila akhlak yang dimiliki rendah, mahasiswa akan mengesampingkan perasaan bersalah tersebut dan lebih memilih berbuat curang. Mahasiswa dengan tingkat religiusitas tinggi menunjukkan bahwa mereka percaya dengan pembalasan dari Tuhannya dari masing-masing agama yang mereka peluk (Herlyana, Sujana dan Prayudi, 2017).

\section{KERANGKA TEORI}

\section{Teori Perilaku Berencana (Theory of Planned Behavior)}

Teori perilaku berencana (Theory of Planned Behavior) adalah teori yang dikembangkan oleh Icek Ajzen dan Martin Fishbein pada tahun 1988. Terdapat tiga konstruk yang berbeda sebagai inti dari Theory of Planned Behaviour (TPB), yaitu sikap terhadap perilaku (attitude towards behavior), norma subyektif (subjective norm) dan kontrol perilaku persepsian (perceived behavior control). Teori perilaku berencana (Theory of Planned Behavior) dapat digunakan untuk menjelaskan perilaku kecurangan akademik mahasiswa. Sebelum melakukan kecurangan, mahasiswa akan memiliki keyakinan-keyakinan tentang hasil yang diperoleh dari perilaku tersebut (behavioral belief). Selanjutnya mahasiswa memutuskan akan melakukan kecurangan atau tidak. Jika hasil yang diperoleh dari perilakunya tersebut menguntungkan, maka mahasiswa tersebut akan melakukannya. Namun apabila hasil yang diperoleh merugikan, maka mahasiswa tidak akan melakukannya (Budiman, 2018).

\section{Teori Kebutuhan McClelland (McClelland's Theory of Needs)}

Teori Kebutuhan McClelland (McClelland's Theory of Needs) adalah teori yang dikembangkan oleh David McClelland dan rekan-rekannya pada tahun 1961. Teori tersebut berfokus pada tiga kebutuhan (McClelland dalam Robbins dan Judge, 2008: 230), yaitu:

1. Kebutuhan pencapaian (need for achievement): Dorongan untuk melebihi, mencapai standar-standar, dorongan untuk berhasil

2. Kebutuhan kekuatan (need for power): Kebutuhan untuk membuat individu lain berperilaku sedemikian rupa sehingga mereka tidak akan berperilaku sebaliknya 
3. Kebutuhan hubungan (need for affiliation): Keinginan untuk menjalin suatu hubungan antar personal

Teori kebutuhan berprestasi dapat dihubungkan dengan perilaku kecurangan akademik. Mahasiswa biasanya mempunyai kebutuhan untuk memperoleh nilai yang baik, dengan begitu mahasiswa mempunyai motivasi berprestasi untuk mencapai tujuannya. Untuk mencapai kebutuhan berprestasi tersebut, mahasiswa kerap kali melakukan berbagai cara, termasuk melakukan kecurangan akademik. Kecurangan yang dilakukan dapat berupa plagiarisme dan mencontek dalam pelaksanaan ujian.

\section{Teori Fraud Diamond}

1) Tekanan (Pressure)

Cressey dalam Tuanakotta (2012: 206) menjelaskan ada konsep dimana seseorang mempunyai kebutuhan terdesak yang tidak dapat diceritakan kepada orang lain yang mana dapat berujung pada tindakan kecurangan. Di bidang akademik, tekanan yang dirasakan oleh mahasiswa dapat berasal dari orang-orang terdekatnya seperti orang tua, saudara, atau temantemannya. Tekanan akademik merupakan situasi dimana seseorang mengalami banyak tuntutan batin yang tidak sesuai dengan situasi yang diinginkan dengan keadaan biologis, psikologis, atau sistem sosial individu tersebut (Damayanti, 2018).

\section{2) Kesempatan (Opportunity)}

Kesempatan juga dapat datang pada saat yang tidak pernah terduga yang dapat membuat sesorang yang sebelumnya tidak berniat melakukan kecurangan malah melakukannya karena adanya kesempatan tersebut. Cressey dalam Tuanakotta (2012:211) berpendapat bahwa pelaku kecurangan memiliki persepsi bahwa ada peluang baginya untuk melakukan kejahatan tanpa diketahui orang lain. Dua komponen tentang persepsi peluang ini yang pertama adalah general information yang merupakan pengetahuan bahwa kedudukan yang mengandung kepercayaan dapat dilanggar tanpa konsekuensi. Pengetahuan ini diperoleh dari apa yang ia dengar dan atau lihat, misalnya dari pengalaman orang lain yang melakukan kecurangan tetapi tidak ketahuan dan tidak diberi sanksi. Kedua, technical skill atau keahlian yang dibutuhkan untuk menjalankan kejahatan tersebut. Mahasiswa biasanya merasa terdapat peluang bagi mereka untuk melakukan tindakan kecurangan tanpa bisa terdeteksi. Hal itu dapat terjadi apabila mahasiswa memperoleh informasi mengenai pelanggaran yang dilakukan.

3) Rasionalisasi (Rationalization) 
Rasionalisasi adalah sikap pembenaran diri sendiri atau alasan yang salah untuk suatu perilaku yang salah (Albrecth dalam Artani dan Wetra, 2017). Pelaku kecurangan biasanya melakukan sikap pembenaran untuk mengurangi perasaan bersalah karena telah melakukan tindakan yang melanggar aturan dan tidak bermoral. Mahasiswa yang melakukan kecurangan akademik selalu mencari pembenaran dengan mengatakan bahwa kecurangan akademik tersebut wajar dilakukan karena berbagai alasan (Artani dan Wetra, 2017).

4) Kemampuan (Capability)

Wolfe dan Hermanson (2004) berpendapat bahwa bahwa teori Fraud Triangle masih dapat dikembangkan. Berdasarkan hasil penelitiannya, mereka mengungkapkan bahwa terdapat faktor lain yang perlu ditambah yaitu kemampuan (capability). Banyak kecurangan akademik yang dilakukan oleh mahasiswa dengan kemampuan yang tepat. Mahasiswa harus memiliki kemampuan untuk mengenali peluang yang ada agar dapat mengambil keuntungan sehingga dapat melakukan kecurangan berulang kali (Aziz dan Novianti, 2016). Pelaku kecurangan akademik biasanya dapat menekan rasa bersalah atau bahkan tidak merasa bersalah setelah melakukan kecurangan akademik, memiliki rasa percaya diri saat melakukan kecurangan dan dapat dengan mudah mengajak teman untuk ikut melakukan kecurangan tersebut.

\section{Tingkat Religiusitas}

Religiusitas dapat diartikan tingkat kepercayaan terhadap Tuhan dalam beragama (Herlyana, Sujana dan Prayudi, 2017). Religiusitas merupakan nilai-nilai agama dalam diri seseorang. Nilai-nilai agama tersebut berkaitan dengan kepercayaan terhadap ajaran-ajaran agama baik dalam hati maupun ucapan. Kepercayaan ini kemudian direalisasikan dalam perbuatan dan tingkah laku sehari-hari (Aviyah dan Farid, 2014).

\section{Kecurangan Akademik (Academic Fraud)}

Kecurangan akademik merupakan perbuatan yang menggunakan cara yang tidak sah untuk mendapatkan keberhasilan akademis atau menghindari kegagalan (Damayanti, 2018). Marsden et. al. (2005) dalam Hariri, Pradana dan Rahman (2018), mengungkapkan kecurangan akademik dibedakan kedalam tiga jenis, yaitu: (1) cheating atau tingkah laku mencontek pada waktu ujian dan mengerjakan tugas; (2) plagiarism yaitu kegiatan mengutip tanpa menyebut sumber; dan (3) falsification yaitu usaha memberikan kesan bahwa suatu "pernyataan tertentu" (yang dinyatakan dalam naskah pelaku kecurangan) telah "dibuktikan" oleh suatu kajian yang 
dilakukan oleh orang lain. Menurut Kusuma (2018), kecurangan akademik yang paling umum dilakukan adalah mencontek (cheating), sedangkan kegiatan kecurangan akademik yang semakin marak di seluruh dunia adalah plagiarisme.

\section{METODE PENELITIAN}

Jenis penelitian yang digunakan dalam penelitian ini adalah penelitian dengan pendekatan kuantitatif. Responden dalam penelitian ini yaitu mahasiswa jurusan akuntansi STIE Madani Balikpapan. Metode ini dilakukan dengan mendatangi secara langsung mahasiswa jurusan akuntansi di STIE Madani Balikpapan untuk memberikan kuesioner atau menyebarkannya secara online dengan menggunakan google form. Karakteristik responden dalam penelitian ini adalah mahasiswa jurusan S1 Akuntansi yang sedang menempuh semester 4 (empat) ke atas. Alasannya karena mahasiswa tersebut telah memiliki pengalaman menjalani beberapa semester perkuliahan dan telah mengetahui karakter-karakter dari beberapa dosen. Selain itu, mahasiswa semester 4 ke atas juga memiliki tingkat berpikir dan kedewasaan yang tinggi serta telah merasakan banyak pengalaman akademik yang memungkinkan mereka melakukan kecurangan akademik.

Metode analisis data dan pengujian hipotesis yang digunakan dalam penelitian ini menggunakan Partial Least Square (PLS) berbasis Structural Equation Model (SEM). Skor koefisien path yang ditunjukkan oleh nilai T-statistik, harus diatas 1,64 untuk hipotesis satu arah (one tailed) dan diatas 1,96 untuk hipotesis dua arah (two tailed) (Jogiyanto dan Abdillah, 2016:63). Karena penelitian ini menggunakan hipotesis satu arah maka skor koefisien path yang ditunjukkan oleh nilai statistik harus diatas 1,64.

\section{HASIL DAN PEMBAHASAN}

Responden merupakan mahasiswa jurusan S1 akuntansi semester IV (empat), semester VI (enam), semester VIII (delapan) dan semester X (sepuluh) di Sekolah Tinggi Ilmu Ekonomi (STIE) Madani Balikpapan. Jumlah kuesioner yang disebar sebanyak 75 kuesioner, sedangkan kuesioner yang kembali hanya 46 kuesioner atau 61,33\%. Dari 46 kuesioner, terdapat 7 kuesioner yang tidak memenuhi kriteria sampel sehingga kuesioner yang dapat diolah hanya 39 kuesioner atau $52 \%$. 
Tabel 4.1

Uji Hipotesis Berdasarkan Path Coefficient

\begin{tabular}{|l|c|c|c|l|}
\hline & $\begin{array}{c}\text { Original } \\
\text { Sample (O) }\end{array}$ & $\begin{array}{c}\text { Standart } \\
\text { Deviation } \\
(\text { STDEV) }\end{array}$ & $\begin{array}{c}\text { T-Statistic } \\
(\mid \mathbf{O} / \text { STDEV|) }\end{array}$ & Keputusan \\
\hline Tekanan $\rightarrow$ Kecurangan Akademik & 0,085 & 0,203 & 0,420 & $\mathrm{H}_{1}$ ditolak \\
\hline Kesempatan $\rightarrow$ Kecurangan Akademik & 0,155 & 0,141 & 1,101 & $\mathrm{H}_{2}$ ditolak \\
\hline Rasionalisasi $\rightarrow$ Kecurangan Akademik & 0,120 & 0,200 & 0,599 & $\mathrm{H}_{3}$ ditolak \\
\hline Kemampuan $\rightarrow$ Kecurangan Akademik & 0,556 & 0,211 & 2,635 & $\mathrm{H}_{4}$ diterima \\
\hline $\begin{array}{l}\text { Tingkat Religiusitas } \rightarrow \text { Kecurangan } \\
\text { Akademik }\end{array}$ & 0,146 & 0,138 & 1,054 & $\mathrm{H}_{5}$ ditolak \\
\hline
\end{tabular}

\section{Pengaruh Tekanan Terhadap Kecurangan Akademik}

Hipotesis pertama $\left(\mathrm{H}_{1}\right)$ dalam penelitian ini menyatakan bahwa tekanan berpengaruh positif terhadap kecurangan akademik. Hasil pengujian pada Tabel 4.1 menunjukkan bahwa variabel tekanan mempunyai nilai $t$-statistic sebesar 0,420 atau lebih kecil dari nilai signifikansi yaitu sebesar 1,64 (one tailed), dengan nilai koefisien (original sample) sebesar 0,085. Hasil uji hipotesis menjelaskan bahwa $\mathrm{H}_{1}$ ditolak. Sehingga dapat disimpulkan bahwa tekanan tidak berpengaruh terhadap kecurangan akademik.

Hasil pengujian ini menunjukkan bahwa meskipun mahasiswa memiliki tekanan yang tinggi, belum tentu mahasiswa akan melakukan tindakan kecurangan akademik. Hal ini bisa terjadi karena banyak mahasiswa yang mampu mengatasi tekanan yang dirasakannya. Hasil penelitian ini sejalan dengan penelitian yang dilakukan oleh Budiman (2018) yang menyatakan bahwa tekanan tidak berpengaruh terhadap perilaku kecurangan akademik mahasiswa. Mahasiswa merasa tidak tertekan atau terbebani dengan hal-hal yang berkaitan dengan perkuliahan sehingga mahasiswa tidak perlu melakukan hal-hal curang untuk mendapatkan sesuatu hal yang bernilai bagi mereka.

\section{Pengaruh Kesempatan Terhadap Kecurangan Akademik}

Hipotesis kedua $\left(\mathrm{H}_{2}\right)$ dalam penelitian ini menyatakan bahwa kesempatan berpengaruh positif terhadap kecurangan akademik. Hasil pengujian pada Tabel 4.1 menunjukkan bahwa variabel kesempatan mempunyai nilai $t$-statistic sebesar 1,101 atau lebih kecil dari nilai signifikansi yaitu sebesar 1,64 (one tailed), dengan nilai koefisien (original sample) sebesar 
0,155. Hasil uji hipotesis menjelaskan bahwa $\mathrm{H}_{2}$ ditolak. Sehingga dapat disimpulkan bahwa kesempatan tidak berpengaruh terhadap kecurangan akademik.

Hasil penelitian ini menunjukkan bahwa tidak semua mahasiswa memilih mengambil kesempatan yang ada untuk melakukan perbuatan kecurangan akademik. Hal ini bisa terjadi karena mahasiswa merasa perlu bertindak jujur selama menjalani masa perkuliahan atau takut jika nanti ketahuan oleh pihak kampus dan menerima sanksi yang berat apabila melakukan kecurangan akademik. Hasil penelitian ini sejalan dengan penelitian Zaini, Carolina dan Setiawan (2015) yang menyatakan bahwa kesempatan tidak berpengaruh terhadap kecurangan akademik mahasiswa. Hal ini disebabkan karena mahasiswa tidak dapat memilih tempat duduk sendiri pada saat ujian sehingga mahasiswa tidak bisa melakukan kecurangan.

\section{Pengaruh Rasionalisasi Terhadap Kecurangan Akademik}

Hipotesis ketiga $\left(\mathrm{H}_{3}\right)$ dalam penelitian ini menyatakan bahwa rasionalisasi berpengaruh positif terhadap kecurangan akademik. Hasil pengujian pada Tabel 4.1 menunjukkan bahwa variabel rasionalisasi mempunyai nilai $t$-statistic sebesar 0,599 atau lebih kecil dari nilai signifikansi yaitu sebesar 1,64 (one tailed), dengan nilai koefisien (original sample) sebesar 0,120. Hasil uji hipotesis menjelaskan bahwa $\mathrm{H}_{3}$ ditolak. Sehingga dapat disimpulkan bahwa rasionalisasi tidak berpengaruh terhadap kecurangan akademik.

Hal ini dapat terjadi karena banyak mahasiswa yang merasa bahwa kecurangan akademik adalah hal yang tidak baik. Sehingga kecurangan akademik yang terjadi bukan karena faktor rasionalisasi tetapi melainkan karena faktor lain. Kecenderungan melakukan kecurangan akademik dapat bergantung pada nilai-nilai etika serta pada keadaan pribadi masing-masing mahasiswa. Mahasiswa yang memiliki nilai-nilai etika yang baik dan lingkungan sekitar yang baik tidak akan merasionalisasikan perbuatan kecurangan akademik sebagai perilaku yang baik. Sehingga mereka cenderung tidak melakukan kecurangan akademik. Hasil penelitian ini konsisten dengan hasil penelitian yang dilakukan oleh Artani dan Wetra (2017) yang menunjukkan bahwa rasionalisasi tidak berpengaruh terhadap kecurangan akademik. Rasionalisasi adalah pembenaran diri sendiri atau alasan yang salah untuk suatu perilaku yang salah. Penelitian ini menunjukkan bahwa adanya alasan sebagai pembenaran untuk melakukan kecurangan akademik tidak selalu mendorong terjadinya perilaku kecurangan akademik. 


\section{Pengaruh Kemampuan Terhadap Kecurangan Akademik}

Hipotesis keempat $\left(\mathrm{H}_{4}\right)$ dalam penelitian ini menyatakan bahwa kemampuan berpengaruh positif terhadap kecurangan akademik. Hasil pengujian pada Tabel 4.1 menunjukkan bahwa variabel kemampuan mempunyai nilai $t$-statistic sebesar 2,635 atau lebih besar dari nilai signifikansi yaitu sebesar 1,64 (one tailed), dengan nilai koefisien (original sample) sebesar 0,556. Hasil uji hipotesis menjelaskan bahwa $\mathrm{H}_{4}$ diterima. Sehingga dapat disimpulkan bahwa kemampuan berpengaruh positif terhadap kecurangan akademik.

Hasil penelitian ini menunjukkan bahwa mahasiswa yang memiliki kemampuan akan melakukan perilaku kecurangan akademik. Mahasiswa mempunyai kemampuan untuk menekan rasa bersalah atau bahkan tidak merasa bersalah ketika melakukan kecurangan akademik. Kemampuan tersebut membuat mahasiswa dapat melihat kesempatan dan mengambil kesempatan tersebut untuk berbuat kecurangan akademik. Hasil penelitian ini didukung oleh penelitian yang dilakukan Budiman (2018) yang menemukan bahwa kemampuan berpengaruh positif terhadap perilaku kecurangan akademik. Mahasiswa yang memiliki kemampuan untuk melakukan ketidakjujuran cenderung akan bertindak melaksanakan kecurangan. Semakin besar kemampuannya untuk melakukan kecurangan maka semakin besar kecenderungan mahasiswa untuk melakukan perilaku kecurangan akademik.

\section{Pengaruh Tingkat Religiusitas Terhadap Kecurangan Akademik}

Hipotesis ketiga $\left(\mathrm{H}_{5}\right)$ dalam penelitian ini menyatakan bahwa tingkat religiusitas berpengaruh negatif terhadap kecurangan akademik. Hasil pengujian pada Tabel 4.1 menunjukkan bahwa variabel rasionalisasi mempunyai nilai $t$-statistic sebesar 1,054 atau lebih kecil dari nilai signifikansi yaitu sebesar 1,64 (one tailed), dengan nilai koefisien (original sample) sebesar 0,146. Hasil uji hipotesis menjelaskan bahwa $\mathrm{H}_{5}$ ditolak. Sehingga dapat disimpulkan bahwa tingkat religiusitas tidak berpengaruh terhadap kecurangan akademik.

Hasil penelitian ini menunjukkan bahwa tinggi rendahnya tingkat religiusitas mahasiswa tidak akan mempengaruhi tindakan mahasiswa dalam melakukan kecurangan akademik. Mahasiswa dengan tingkat religiusitas tinggi dapat tetap melakukan kecurangan akademik. Hal ini karena terdapat faktor lain yang membuat mahasiswa mengabaikan nilai-nilai agama yang dimilikinya dan melakukan kecurangan akademik. Faktor lain tersebut dalam penelitian ini adalah faktor kemampuan. Hasil penelitian ini didukung oleh penelitian yang dilakukan oleh Yendrawati dan Akbar (2019) yang menemukan bahwa tingkat religiusitas (Islamic ethics) tidak berpengaruh terhadap perilaku kecurangan akademik (academic fraudulent behaviors). 
Religiusitas (Islamic ethics) pada dasarnya didasarkan pada iman, oleh karena itu rasionalisasi yang rendah dalam diri siswa bahwa iman sangat penting dalam setiap pekerjaan yang mereka lakukan akan mengurangi kesadaran dan keyakinan mereka bahwa setiap perbuatan mereka diawasi dan disaksikan oleh Tuhan.

\section{PENUTUP}

Berdasarkan hasil penelitian, maka dapat disimpulkan sebagai berikut:

1. Tekanan tidak berpengaruh terhadap kecurangan akademik. Meskipun mahasiswa memiliki tekanan yang tinggi, belum tentu mahasiswa akan melakukan tindakan kecurangan akademik.

2. Kesempatan tidak berpengaruh terhadap kecurangan akademik. Tidak semua mahasiswa memilih mengambil kesempatan yang ada untuk melakukan perbuatan kecurangan akademik.

3. Rasionalisasi tidak berpengaruh terhadap kecurangan akademik. Banyak mahasiswa yang merasa bahwa kecurangan akademik adalah hal yang tidak baik.

4. Kemampuan berpengaruh positif terhadap kecurangan akademik. Mahasiswa yang memiliki kemampuan akan melakukan perilaku kecurangan akademik.

\section{DAFTAR PUSTAKA}

Ajzen, Icek. 1991. The Theory of Planned Behavior. Organizational Behavior and Human Decision Processes. Volume 50: 179-211.

Andayani, Yozi, dan Vita Fitria Sari. 2019. Pengaruh Daya Saing, Gender, Fraud Diamond Terhadap Perilaku Kecurangan Akademik Mahasiswa (Studi Kasus Pada Mahasiswa S1 Akuntansi Universitas Negeri Padang). Jurnal Eksplorasi Akuntansi. Volume 1(3): 14581471.

Artani, Ketut Tri Budi, dan I Wayan Wetra. 2017. Pengaruh Academic Self Efficacy dan Fraud Diamond Terhadap Perilaku Kecurangan Akademik Mahasiswa Akuntansi di Bali. Jurnal Riset Akuntansi JUARA. Volume 7(2): 123-132.

Aviyah, Evi, dan Muhammad Farid. 2014. Religiusitas, Kontrol Diri dan Kenakalan Remaja. Persona, Jurnal Psikologi Indonesia. Volume 3(2): 126-129.

Aziz, Muhammad Rusydi, dan Nurlita Novianti. 2016. Analisis Pengaruh Fraud Diamond, Integritas, dan Religiusitas Terhadap Perilaku Kecurangan Akademik Mahasiswa (Studi Kasus Pada Mahasiswa Akuntansi Akuntansi Konsentrasi Syariah Universitas Brawijaya). Jurnal Ilmiah Mahasiswa Fakultas Ekonomi dan Bisnis. Volume 4(2): 1-22

Bolin, Aaron U. 2004. Self-Control, Perceived Opportunity, and Attitudes as Predictors of Academic Dishonesty. The Journal of Psychology. Volume 138(2): 101-114. 
Budiman, Nita Andriyani. 2018. Perilaku Kecurangan Akademik Mahasiswa: Dimensi Fraud Diamond dan Gone Theory. Akuntabilitas: Jurnal Ilmu Akuntansi. Volume 11(1): 75-90.

Damayanti, Christina Putri. 2018. Hubungan Faktor-Faktor Dalam Dimensi Fraud Triangle Terhadap Perilaku Kecurangan Akademik Mahasiswa Program Studi Pendidikan Akuntansi Universitas Sanata Dharma Yogyakarta. Skripsi. Yogyakarta: Fakultas Keguruan dan Ilmu Pendidikan Universitas Sanata Dharma.

Dewati, Pranamya, dan Ikhwanul Habibi. 2018. Empat Akademisi Tanah Air yang Terjerat Kasus Plagiarisme. https://kumparan.com/kumparannews/4-akademisi-tanah-air-yangterjerat-kasus-plagiarisme. Diakses 14 Desember 2019. (Pukul 20.22).

Dirdjosumarto, Yulianto. 2016. Menyontek (Cheating) - Kecurangan Akademik. Ekspansi. Volume 8(1): 277-290.

Fihandoko, Surya, dan M. Achsin. 2014. Pengaruh Sifat Sinisme, Lingkungan dan Sifat Machiavellian Terhadap Tindakan Kecurangan Akademik. Jurnal Ilmiah Mahasiswa FEB Universitas Brawijaya. Volume 3(1): 1-35.

Ghozali, Imam. 2014. Structural Equation Modeling: Metode Alternatif dengan Partial Least Square (PLS). Edisi 4. Semarang: Universitas Diponegoro.

Hariri, Ayub Wijayati Sapta Pradana, dan Fahrurrozi Rahman. 2018. Mendeteksi Perilaku Kecurangan Akademik dengan Perspektif Fraud Diamond Theory. JU-ke. Volume 2(1): $1-11$.

Herlyana, Made Vonny, Edy Sujana, dan Made Aristia Prayudi. 2017. Pengaruh Religiusitas dan Spiritualitas Terhadap Kecurangan Akademik Mahasiswa (Studi Empiris Pada Mahasiswa Universitas Pendidikan Ganesha Singaraja). E-Journal S1 Ak Universitas Pendidikan Ganesha. Volume 8(2): 1-11.

International Center for Academic Integrity. Statistic. https://www.academicintegrity.org/statistics/. Diakses 13 Desember 2019. (Pukul 20.09).

Jaya, I Gede Nyoman Mindra, dan I Made Sumertajaya. 2008. Pemodelan Persamaan Struktural dengan Partial Least Square. Semnas Matematika dan Pendidikan Matematika. 118-132.

Jiwandono, Rahmat. 2019. UGM Temukan Kesamaan Disertasi Rektor Unnes dengan Skripsi Mahasiswa, Belum Tentu Plagiarisme. https://kabar24.bisnis.com/read/20191127/15/1175075/ugm-temukan-kesamaandisertasi-rektor-unnes-dengan-skripsi-mahasiswa-belum-tentu-plagiarisme. Diakses 14 Desember 2019. (Pukul 20.03).

Jogiyanto. 2007. Sistem Informasi Keprilakuan. Yogyakarta: Penerbit ANDI. 2018. Pedoman Survei Kuesioner: Mengembangkan Kuesioner Mengatasi Bias dan Meningkatkan Respon. Yogyakarta: BPFE. 
Jogiyanto, dan Willy Abdillah. 2016. Konsep dan Aplikasi PLS (Partial Least Square) Untuk Penelitian Empiris. Yogyakarta: BPFE.

KBBI Daring. 2016. Religi. https://kbbi.kemdikbud.go.id/entri/religi. Diakses 5 Februari 2020. (Pukul 20.07).

16.44).

2012. Tekan. https://kbbi.web.id/tekan. Diakses 14 Februari 2020. (Pukul

. 2012. Mampu. https://kbbi.web.id/mampu. Diakses 14 Februari 2020. (Pukul 17.02).

2012. Rasionalisasi. https://kbbi.web.id/rasionalisasi. Diakses 14 Februari 2020. (Pukul 17.13).

Kusuma, Muhammad Dwi Faisal. 2018. Faktor-Faktor yang Mempengaruhi Mahasiswa Melakukan Tindakan Kecurangan Akademik dengan Perspektif Fraud Diamond dan Religiusitas (Studi Pada Mahasiswa Akuntansi Universitas Islam Indonesia). Skripsi. Yogyakarta: Fakultas Ekonomi Universitas Islam Indonesia.

Lestari, Daurina, dan Cahyo Edi. 2019. Rektor Universitas Negeri Semarang Diduga Plagiat Skripsi Mahasiswanya. https://www.vivanews.com/berita/nasional/21506-rektoruniversitas-negeri-semarang-diduga-plagiat-skripsi-mahasiswanya?medium=autonext.

Diakses 14 Desember 2019. (Pukul 19.44).

Maku, Sabrin. 2019. Akibat Plagiat, Kampus Unisan Gorontalo Tidak Bisa Terima Mahasiswa Baru. https://daerah.sindonews.com/read/1424389/174/akibat-plagiat-kampus-unisangorontalo-tidak-bisa-terima-mahasiswa-baru-1564224259. Diakses 14 Desember 2019. (Pukul 20.16).

Murdiansyah, Isnan, Made Sudarma, dan Nurkholis. 2017. Pengaruh Dimensi Fraud Diamond Terhadap Perilaku Kecurangan Akademik (Studi Emiris Pada Mahasiswa Magister Akuntansi Universitas Brawijaya). Jurnal Akuntansi Aktual. Volume 4(2): 121-133.

Nurkhin, Ahmad, dan Fachrurrozie. 2018. Analisis Pengaruh Dimensi Fraud Diamond Terhadap Perilaku Kecurangan Akademik Mahasiswa Pendidikan Akuntansi UNNES. Liabilities Jurnal Pendidikan Akuntansi. Volume 1(1): 1-12.

Pamungkas, Desiana Dwi. 2015. Pengaruh Faktor-Faktor Dalam Dimensi Fraud Triangle Terhadap Perilaku Kecurangan Akademik Siswa Kelas XI Akuntansi SMK Negeri 1 Tempel Tahun Ajaran 2014/2015. Skripsi. Yogyakarta: Fakultas Ekonomi Universitas Negeri Yogyakarta.

Peraturan Menteri Pendidikan Nasional Nomor 17 Tahun 2010 Tentang Pencegahan dan Penanggulangan Plagiat di Perguruan Tinggi.

Purnamasari, Desi. 2013. Faktor-Faktor yang Mempengaruhi Kecurangan Akademik Pada Mahasiswa. Educational Psychology Journal. Volume 2(1): 13-21. 
Ridhayana, Risna, Resmiyati Ansar, dan Suriana A.H. Mahdi. Pengaruh Fraud Triangle dan Tingkat Religiusitas Terhadap Perilaku Kecurangan Akademik (Studi pada Mahasiswa S-1 Universitas Khairun). Jurnal Riset Akuntansi. Volume 5(2): 112-121.

Ristianingsih, Ika. 2017. Telaah Konsep Fraud Diamond Theory Dalam Mendeteksi Perilaku Fraud di Perguruan Tinggi. SNAPER-EBIS 2017. Oktober 27-28. Prosiding Seminar Nasional dan Call For Paper Ekonomi dan Bisni: 128-139

Riyanti. 2015. Intensi Mencontek Ditinjau dari Theory of Planned Behavior. Jurnal Ilmiah Psikologi Terapan. Volume 3(2): 249-267.

Robbins, Stephen P., dan Timothy A. Judge. 2008. Perilaku Organisasi. Edisi 12. Jakarta: Salemba Empat.

Sari, Dewi Surtika, Rispantyo, dan Djoko Kristianto. 2017. Pengaruh Dimensi Fraud Triangle (Tekanan, Kesempatan dan Rasionalisasi) Terhadap Perilaku Kecurangan Akademik pada Mahasiswa. Jurnal Akuntansi dan Sistem Teknologi Informasi. Volume 13(4): 464472.

Seni, Ni Nyoman Anggar, dan Ni Made Dwi Ratnadi. 2017. Theory of Planned Behavior Untuk Memprediksi Niat Berinvestasi. E-Jurnal Ekonomi dan Bisnis Universitas Udayana. Volume 6(12): 4043-4068.

STIE Madani Balikpapan. 2018. Profil. http://stiemadani.ac.id/index.php/sejarah-stie-madani/. Diakses 15 Januari 2020. (Pukul 20.36).

Sugiyono. 2016. Metode Penelitian Kuantitatif, Kualitatif dan R\&D. Bandung: Alfabeta.

Thoha, Mifta. 2014. Perilaku Organisasi: Konsep Dasar dan Aplikasinya. Edisi Pertama. Cetakan ke-23. Jakarta: Rajawali Pers.

Tuanakotta, Theodorus M. 2012. Akuntansi Forensik \& Audit Investigatif. Edisi Dua. Jakarta: Salemba Empat.

Umar, Husein. 2013. Metode Penelitian Untuk Skripsi dan Tesis Bisnis. Edisi 2. Cetakan ke12. Jakarta: Rajawali Pers.

Widianto, Andri, dan Yeni Priatna Sari. 2017. Deteksi Kecurangan Akademik pada Mahasiswa D III Akuntansi Politeknik Harapan Bersama Tegal dengan Model Fraud Triangle. Jurnal AKSI (Akuntansi dan Sistem Informasi). Volume 2(1): 29-37

Wisnumurti, Putri Adininggar. 2017. Pengaruh Dimensi Fraud Diamond dan Prokrastinasi Akademik Terhadap Kecurangan Akademik Siswa Kelas X dan XI Kompetensi Keahlian Akuntansi di SMK Negeri 2 Kota Tegal Tahun 2016/2017. Skripsi. Semarang: Fakultas Ekonomi Universitas Negeri Malang.

Wolfe, David T., and Dana R. Hermanson. 2004. The Fraud Diamond: Considering the Four Elements of Fraud. CPA Journal. Volume 74(12): 38-42. 
Yendrawati, Reni, dan Andi Wahyu Akbar. 2019. The Influence of the Fraud Triangle and Islamic Ethics on Academic Fraudulent Behaviors. Review of Integrative and Economics Research. Volume 8(4): 441-457.

Yudiana, Anastasya Putri, dan Hexana Sri Lastanti. 2017. Analisis Pengaruh Dimensi Fraud Diamond Terhadap Perilaku Kecurangan Akademik Mahasiswa Fakultas Ekonomi (Studi Empiris Mahasiswa Fakultas Ekonomi dan Bisnis Universitass Trisakti). Jurnal Akuntansi Trisakti. Volume 4(1): 1-21.

Zaini, Mohammad, Anita Carolina, dan Achdiar Redy Setiawan. 2015. Analisis Pengaruh Fraud Diamond dan Gone Theory Terhadap Academic Fraud (Studi Kasus Mahasiswa Akuntansi Se-Madura). Simposium Nasional Akuntansi 18.

Zamzam, Irfan, Suriana AR. Mahdi, dan Resmiyati Ansar. 2017. Pengaruh Diamond Fraud dan Tingkat Religiusitas Terhadap Kecurangan Akademik (Studi pada Mahasiswa S-1 di Lingkungan Perguruan Tinggi Se Kota Ternate). Jurnal Ilmiah Akuntansi Peradaban. Volume 3(2): 1-24 